\title{
Sweet corn crop response to different dripline spacings in the dry Medi- terranean area
}

\author{
Ibrahim MUBARAK $^{1,2}$, Mussaddak JANAT ${ }^{1}$
}

Sweet corn crop response to different dripline spacings in the dry Mediterranean area

Abstract: Increasing the spacing between driplines is the most significant factor in reducing the high initial costs of drip irrigation system. A two-year field study (2017 and 2018) was conducted on a clay loam soil to evaluate the effects of different dripline spacings $(75,150,225$, and $300 \mathrm{~cm})$ on sweet corn yields, soil water status, and irrigation water use efficiency (IWUE) in the dry Mediterranean area. Results showed that the average husked cob yield (HCY) and IWUE were significantly decreased as the dripline spacing increased. HCY was 13.93, $12.30,9.18$, and $6.86 \mathrm{t} \mathrm{ha}^{-1}$, for dripline spacing of 75, 150, 225, and $300 \mathrm{~cm}$, respectively, for an average irrigation water depth of $725 \mathrm{~mm}$. Both soil water storages and yields decreased with distance from the dripline. The 150-, 225- and $300 \mathrm{~cm}$ dripline spacings yielded 11.7, 34.0 and $50.8 \%$ less than the $75 \mathrm{~cm}$ dripline spacing, but these wider dripline spacings provided 50, 67 and $75 \%$ less unit-area cost, respectively. However, these reductions in crop yield did not justify the extra cost of the closer dripline spacing, at low crop prices and high dripline costs. Finally, further studies are needed to benefit from the higher initial unit-area cost savings obtained under the wider dripline spacings.

Key words: drip irrigation; clay loam soil; soil water storage; husked cob yield; row-to-row variations
Received December 16, 2019; accepted August 11, 2020. Delo je prispelo 16. decembra 2019, sprejeto 11. avgusta 2020.
Odziv sladke koruze na različne namestitve namakalnih naprav v suhem sredozemskem območju

Izvleček: Povečevanje razdalje med namakalnimi cevmi je najpomembnejši dejavnik pri zmanjševanju začetnih stroškov pri namestitvi namakalnega sistema. Za ovrednotenje učinkov različne namestitve namakalnih cevi $(75,150,225$, in $300 \mathrm{~cm})$ na pridelek sladke koruze, stanja vode $\mathrm{v}$ tleh in na učinkovitost zalivanja (IWUE) je bil izveden dvoletni poljski poskus (2017 in 2018) v sušnem sredozemskem območju. Rezultati so pokazali, da sta se poprečni pridelek oličkanih storžev (ICY) in učinkovitost zalivanja (IWUE) značilno zmanjšala s povečevanjem razdalje med zalivalnimi cevmi. HCY je bil 13,93, 12,30, 9,18, in $6,86 \mathrm{t} \mathrm{ha}^{-1}$, pri razmaku zalivalnih cevi $75,150,225$, in $300 \mathrm{~cm}$, pri poprečni globini zalivanja $725 \mathrm{~mm}$. Z oddaljenostjo od namakalnih cevi sta se zmanjševala pridelek in vsebnost vode $\mathrm{v}$ tleh. Namestitev namakalnih cevi na 150, 225 in $300 \mathrm{~cm}$ je dala za $11,7,34,0$ in $50,8 \%$ manj pridelka v primerjavi $\mathrm{z}$ namestitvijo na $75 \mathrm{~cm}$, a je imela ta namestitev namakalnih cevi za 50,67 in $75 \%$ manj stroškov na enoto površine. Kljub temu zmanjšanje pridelka ni upravičilo dodatnih stroškov za gostejšo namestitev namakalnih cevi zaradi nizkih cen pridelka in visokih stroškov namakalnih cevi. Zaključimo lahko, da so potrebne dodatne raziskave prihrankov visokih začetnih stroškov na enoto površine pri večjih razmakih namakalnih cevi.

Ključne besede: kapljični namakalni sistem; ilovnato-peščena tla; zadrževanje vode $\mathrm{v}$ tleh; pridelek oličkanih storžev; razlike med razdaljami med namakalnimi cevmi 


\section{INTRODUCTION}

Sweet corn (Zea mays L. convar. saccharata Koern. var. rugosa) is one of the most popular vegetables grown for human consumption as either a fresh or processed product. Fresh consumption of sweet corn by boiling or grilling is rapidly increasing worldwide. Husked cobs of large sizes are more attractive in market. Moreover, stalks and leaves are used for animal feed. Efficient water use, where water resources are scarce as in the dry Mediterranean area, is an urgent need to address the sustainability of crop production for increasing food demands.

Drip irrigation system has been proved to improve water use efficiency and offer yield enhancement compared with sprinkle and surface irrigation (Clemmens, 2002; Tiercelin, 2007). However, one of the greatest barriers to the widespread adoption of drip irrigation is its high initial investment cost compared with the other irrigation systems. The cost of driplines (laterals) represents a large part of the initial cost. Bozkurt et al. (2006) reported that the cost of pipes (all tubing and laterals) was about $45 \%$ of the total cost of a drip irrigation system. Therefore, adoptation of economically-sound and scientifically-proven techniques is a practical tool for reducing the high initial cost, which compiles with best management practices.

In this context, increasing the spacing between driplines would be one of the most significant factors. For example, using a dripline for two crop rows rather than for one would half the number of driplines as per crop rows, and therefore, would reduce the initial cost of irrigation system (Henggeler, 1995; Camp et al., 1997; Camp, 1998; Lamm and Trooien, 2003; Bozkurt et al., 2006; Zhou et al., 2017; Al-hurmuzi and Topak, 2018; Mubarak, 2020a and b). In regions such as the humid Mediterranean region and the wetter region of Virginia and Kansas in USA, that normally receive substantial volume of rainfall at planting time, changing dripline spacings have not greatly influenced germination or final yield; and thus yield was not sufficiently reduced to warrant the extra cost of a closer dripline spacing (Camp et al., 1989; Spurgeon and Manges, 1990; Powell and Wright, 1993; Camp et al., 1997; Lamm et al., 1997; Al-hurmuzi and Topak, 2018). On the other hand, in regions where rainfall is unreliable throughout the year, and/or near-surface soil water that is required for seed germination often evaporates due to the high climatic demand, wider dripline spacings require excessive pre-planting irrigation or using another irrigation system as sprinkle system in order

Table 1: Some climatic data for the experimental station during both growing seasons (2017 and 2018), and the average of last 20 years

\begin{tabular}{|c|c|c|c|c|c|}
\hline Variable & Year & Apr. & May & Jun. & Jul. \\
\hline & 2017 & 9.7 & 14.4 & 17.2 & 20.6 \\
\hline & 2018 & 10.0 & 15.6 & 18.2 & 19.8 \\
\hline \multirow[t]{3}{*}{$T_{\min }\left({ }^{0} \mathrm{C}\right)$} & 20-year average & 10.1 & 14.1 & 17.6 & 19.3 \\
\hline & 2017 & 26.2 & 31.6 & 35.7 & 40.6 \\
\hline & 2018 & 27.2 & 31.5 & 34.6 & 36.9 \\
\hline \multirow[t]{3}{*}{$T_{\max }\left({ }^{0} \mathrm{C}\right)$} & 20-year average & 25.3 & 30.4 & 35.0 & 37.4 \\
\hline & 2017 & 19.2 & 24.9 & 28.4 & 31.1 \\
\hline & 2018 & 19.9 & 25.7 & 27.7 & 28.8 \\
\hline \multirow[t]{3}{*}{$T_{\text {average }}\left({ }^{0} \mathrm{C}\right)$} & 20-year average & 18.1 & 23.6 & 27.7 & 29.4 \\
\hline & 2017 & 63.1 & 57.9 & 56.3 & 56.0 \\
\hline & 2018 & 54.8 & 51.5 & 59.6 & 55.6 \\
\hline \multirow[t]{3}{*}{$R H(\%)$} & 20-year average & 60.9 & 56.5 & 56.3 & 60.7 \\
\hline & 2017 & 5.7 & 7.6 & 9.0 & 10.3 \\
\hline & 2018 & 6.8 & 7.8 & 8.8 & 10.3 \\
\hline \multirow[t]{3}{*}{$E T_{0}\left(\mathrm{~mm}\right.$ day $\left.^{-1}\right)$} & 20 -year average & 5.6 & 7.5 & 9.4 & 10.4 \\
\hline & 2017 & 0.0 & 0.0 & 0.0 & 0.0 \\
\hline & 2018 & 14 & 0.0 & 0.0 & 0.0 \\
\hline Rainfall (mm) & 20 -year average & 5.9 & 4.2 & 0.0 & 0.0 \\
\hline
\end{tabular}

$T_{\min }:$ minimum temperature, $T_{\max }$ : maximum temperature, $T_{\text {average }}$ : average temperature, $R H$ : relative air humidity, $E T_{0}$ : reference evapotranspiration. 
to suitably germinate the seeds (Henggeler, 1995; Howell et al., 1997; Bordovsky and Porter, 2003). Failing to do so would potentially result in poor seed germination and crop establishment (Charlesworth et al., 1998; Charlesworth and Muirhead, 2003). The problem could be worse for coarser soils where water movement is dominated by gravity rather than capillary forces (Thorburn et al., 2003), or for soils that have a relatively high clay content where shrinking-swelling cycles result in large cracks (Howell et al., 1997). Moreover, even in locations where rainfall is reasonably reliable, row-to-row yield variation may increase with increasing dripline spacings. Yields from plant rows away from driplines were found to be significantly lower than those from rows adjacent to the driplines (Kruse and Israeli, 1987; Lamm et al., 1997; Bosch et al., 1998; Bozkurt et al., 2006; Mubarak, 2020a). Nevertheless, to the best of our knowledge, very few findings are presently available on the use of one dripline for three or four rows of sweet corn grown in the dry Mediterranean area. Under such arrangement, the number per unit area of driplines and, therefore, their initial cost decreased to a third or to a quarter, as compared with the conventional pattern of one dripline for each plant row.

The specific objective was to evaluate the effects of dripline spacings on sweet corn yields, soil water status, and irrigation water use efficiency. Results may introduce practical alternatives of drip-irrigated sweet corn production system to meet sustainable production and water shortage in the dry Mediterranean area.

\section{MATERIALS AND METHODS}

\subsection{STUDY AREA}

Field experiments were conducted at the Deir AlHajar Agricultural Experiment Station, south of Damascus, Syria $\left(33^{\circ} 20^{\prime} \mathrm{N}, 36^{\circ} 26^{\prime} \mathrm{E}\right.$, altitude $\left.600 \mathrm{~m}\right)$, for two consecutive growing seasons 2017 and 2018. The area is characterized by a dry Mediterranean type climate, with an average annual precipitation of about $120 \mathrm{~mm}$ (October-May). Some climate data during the course of experi-
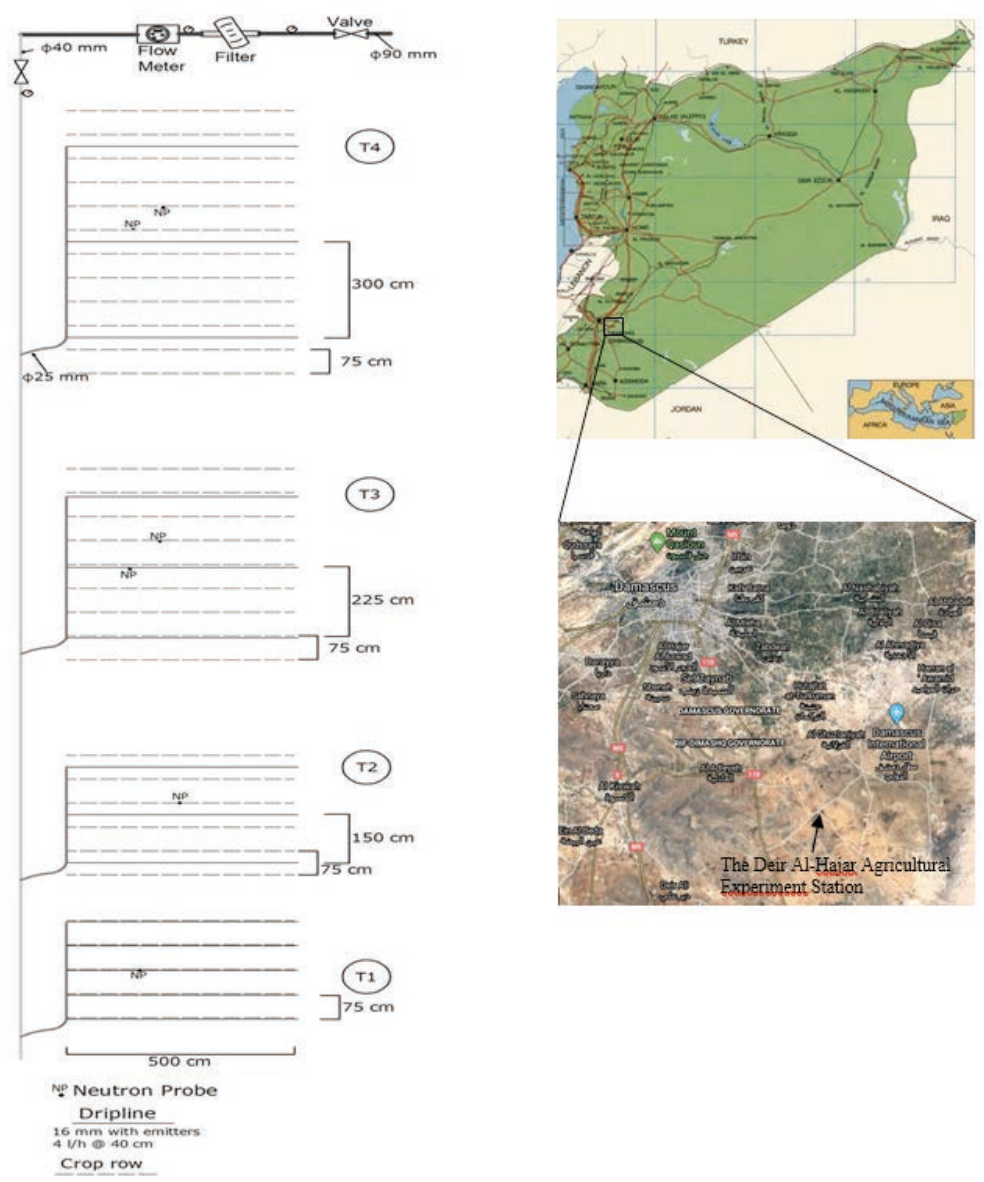

Figure 1: Outline of one replicate according to dripline spacings. T1, T2, T3, and T4 represent S75, S150, S225, and S300, respectively, and maps of the geographical position in Syria of the experimental station. 
ments were collected from a weather station located close to the study site. The climate data for both years as well as the 20-year average are reported in Table 1.

The soil is classified as a clay loam with $27.8 \%$ sand, $42.7 \%$ silt, and $29.5 \%$ clay, with a bulk density of about $1.35 \mathrm{~g} \mathrm{~cm}^{-3}$. Before planting, the topsoil $(0-30 \mathrm{~cm})$ was characterized by about $1 \%$ of organic matter, $\mathrm{pH}$ of 8.0 ,

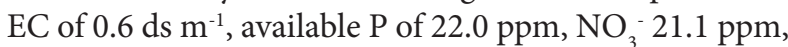
$\mathrm{NH}_{4}^{+} 14.7 \mathrm{ppm}$.

\subsection{EXPERIMENTAL DESIGN}

The experiment was arranged in a randomized complete block design (RCB design) with four dripline spacings and three replicates. The four dripline spacings composed of: T1 (S75) in which one dripline was used for each crop row (1:1), T2 (S150) in which one dripline served two crop rows (1:2), T3 (S225) in which one dripline served three crop rows (1:3), and T4 (S300) in which one dripline served four crop rows (1:4). Singlerow production system was used, i.e., conventional plant row widths, in which corn was sown with a regular row spacing of $75 \mathrm{~cm}$ and spaced $20 \mathrm{~cm}$ apart within row, giving a plant density of about 67,000 plants ha ${ }^{-1}$. Each experimental unit in $\mathrm{S} 75$ contained five $75 \mathrm{~cm}$ crop rows and five $75 \mathrm{~cm}$ driplines. In S150, each experimental unit contained six $75 \mathrm{~cm}$ crop rows and three $150 \mathrm{~cm}$ driplines. In S225, each experimental unit contained nine $75 \mathrm{~cm}$ crop rows and three $225 \mathrm{~cm}$ driplines. In S300, each experimental unit contained twelve $75 \mathrm{~cm}$ crop rows and three $300 \mathrm{~cm}$ driplines (Fig. 1). The length of each experimental unit was $5 \mathrm{~m}$. The number of crop rows per unit area (per hectare) and, therefore, the plant density (about 67,000 plants ha-1) were maintained equal for all treatments.

The field was conventionally prepared, i.e., ploughed and disked before planting. A sufficient spacing was maintained between plots to minimize water intervention among treatments. Sweet corn (Zea mays 'Silver Queen White') was sown on April the $18^{\text {th }}$ and the $3^{\text {rd }}$ in the 2017 and 2018 growing seasons, respectively. As the area was not too large, the hand sowing was used. The plant densities after establishment and at harvest were similar within the treatments. Weeds were manually removed many times during both cropping seasons. Because of the lack of rainfall and the inability of drip irrigation to germinate corn seeds especially in plots with wider dripline spacings, a secondary lateral move irrigation system (available on site) was used at the beginning of each season. It was used two times during the first month with $100 \mathrm{~mm}$ water applied in each growing season. After that, the drip irrigation started on as scheduled and continued until termination. Driplines (GR type, $16 \mathrm{~mm}$ diameter) with a built-in $40-\mathrm{cm}$ emitter spacing and a nominal flow rate of $41 \mathrm{hr}^{-1}\left(101 \mathrm{hr}^{-1} \mathrm{~m}^{-1}\right)$ were used.

\subsection{DATA MANAGEMENT}

The climate data were used to calculate the reference evapotranspiration $\left(E T_{0}\right)$ using the FAO PenmanMonteith equation. Sweet corn crop data, i.e., growth stages in days, crop coefficient value $(K c)$ at each growth stage, were obtained from FAO databases (FAO, 1998). The duration of the initial, development, mid-season and late season growth stages were 20,30,40, and 10 days, respectively. The crop coefficient $(K c)$ is basically the ratio of the crop evapotranspiration $(E T c)$ to the reference evapotranspiration $\left(E T_{0}\right)$, and it represents an integration of the effects of characteristics that distinguish the sweet corn crop from reference grass. $K c$ values were $0.3,1.15$, and 1.05 for initial, mid-season and late season growth stages, respectively. Deviation of the Kc in both mid-season and late season stages from the reference value ' 1 ' is mainly due to differences in crop height and resistance between the grass reference surface and the sweet corn crop and weather conditions (FAO, 1998). Daily crop evapotranspiration (crop water requirement, ETc) was calculated by multiplying the daily $E T_{0}$ by the crop coefficient $K c$ within each growth stage.

Crop water requirement data were used for scheduling irrigation. Corn crop was irrigated once a week, because it is usually more convenient to adjust the irrigation schedule weekly. The weekly sum of daily ETc values was used to adjust the schedule for the following week. The weekly adjustment ensures that soil water content in the rootzone was replenished. The same volumes of water per unit area were applied to the other treatments. In other words, the irrigation water depth applied was equal for all treatments. However, treatments differed in terms of irrigation times, as calculated by Eq. (1), due to the differences in dripline spacings.

Irrigation time $(\mathrm{hr})=\frac{\text { dripline spacing }(\mathrm{cm}) \times \text { emitter spacing }(\mathrm{cm}) \times \text { irrigation amount }(\mathrm{mm})}{10000 \times \text { emitter rate }\left(1 \mathrm{hr}^{-1}\right)}$

Volumetric soil water content was observed using neutron scattering technique (NP), on a weekly basis each growing season (about 72 hours after irrigation event). The probe was in-situ calibrated before sowing. Neutron probe access tubes were installed in the crop rows according to the distance from the dripline (Fig 1). In other words, one soil profile was tested in both S75 and S150, whereas two soil profiles were studied in both S225 
and S300 according to the location of plant row relative to the dripline: (a) at the crop row close to the dripline, and (b) at the distant crop row from the dripline.

The total soil water storage (SWS) from the soil surface to the root zone depth $(\mathrm{Zm}=1.2 \mathrm{~m})$ were calculated by the following equation:

$$
\mathrm{SWS}=\int_{0}^{Z \mathrm{~m}} \Theta(z) \mathrm{dz}
$$

where $\theta$ is volumetric soil water content $\left(\mathrm{cm}^{3} \mathrm{~cm}^{-3}\right)$, and $z$ is soil depth (m). For the purpose of comparison, changes over time in SWS which were directly measured under plants, were jointly plotted, i.e., presented together graphically for the purposes of comparison. In order to check soil water stress under crop rows, the parameters describing the water stress response function as suggested by Feddes et al. (1978), are also used. This function defines the manner in which transpiration is reduced below potential when the soil is no longer able to supply the required amount of water by plant under the prevailing climatic conditions. This function assigns plant root water uptake rates according to the local soil water pressure head $(h)$, at any point in the root zone. Water uptake in this model is assumed to be zero close to saturation. Water uptake is considered optimal between two specific values of pressure head $h_{2}$ and $h_{3}$. While for soil water pressure heads between $h_{3}$ and $h_{4}$, water uptake decreases. Root water uptake is also considered to be zero for soil water pressure heads less than the wilting point pressure head (more negative, $h<h_{4}$ ). The values of soil water content $(\theta)$ corresponding to $h_{2}, h_{3}$, and $h_{4}$ were calculated as $44.5,23.2$, and $13.6 \mathrm{~cm}^{3} \mathrm{~cm}^{-3}$, respectively, for sweet corn crop and for the clay loam soil, according to Feddes et al. (1978). Soil water storages corresponding to these root water uptake parameters were also presented graphically.

For each cropping season, the field was fertilized in early winter with $46.0 \mathrm{~kg}$ of $\mathrm{P}_{2} \mathrm{O}_{5} \mathrm{ha}^{-1}$ as triple super phosphate (TSP). However, N-fertilizer as urea $46 \%$ solution (150 $\mathrm{kg} \mathrm{N} \mathrm{ha}^{-1}$ ) was applied in two equally split applications. The $1^{\text {st }}$ was applied at sowing day, while the $2^{\text {nd }}$ was one month later. Thus, all plots received the same amounts of both $\mathrm{N}$ and $\mathrm{P}$ fertilizers.

Regarding fresh marketable yield, harvest was done when corn silk began to turn brown, which occurred approximately at the milky stage with seed water content of about 70-75\% (100 days after planting for both growing seasons). A $2 \mathrm{~m}$ row length (10 plants) from the centre of each plot (individual replicate) was selected. For plots with wider dripline spacings (S225 and S300) two adjacent plant rows which represented the nearest and the furthest crop rows from dripline, were selected to estimate an integrated measured parameters for these treatments, and to assess the yield distribution according to the row distance from dripline. The heights of selected plants were measured from the soil surface up to the beginning of tassels. Fresh green cobs from selected plants were hand harvested. Mass (CM), length (CL), and diameter (CD) of husked cobs were measured. All cobs with good grain filling and longer than $10 \mathrm{~cm}$ were considered marketable cobs according to the common corn-farming practices in the area. Following the harvest of husked cobs, aboveground vegetative parts of selected plants were also harvested and oven dried at $70{ }^{\circ} \mathrm{C}$ until constant mass for dry matter yield determination. Mass of cobs and vegetative parts were converted into unit area yields and expressed as $\mathrm{t} \mathrm{ha} \mathrm{h}^{-1}$.

Irrigation water use efficiency (IWUE) was determined by dividing yield by the irrigation water amount applied $\left(\mathrm{I}, \mathrm{m}^{3}\right)$, and expressed as $\mathrm{kg}$ per $\mathrm{m}^{3}$ of water. It was calculated for husked cob yield $\left(I W U E_{h c}\right)$ and dry matter yield ( $\left.I W U E_{d m}\right)$ using equations (3 and 4), respectively.

$$
\begin{gathered}
\mathrm{IWUE}_{\mathrm{hc}}=\frac{\mathrm{HCY}}{\mathrm{I}} \\
\mathrm{IWUE}_{\mathrm{dm}}=\frac{\mathrm{DMY}}{\mathrm{I}}
\end{gathered}
$$

\subsection{STATISTICAL DATA ANALYSIS}

The measured parameters, i.e., plant height $(\mathrm{H})$, mass (CM), length (CL), and diameter (CD) of husked cobs, husked cob yield (HCY), dry matter yield (DMY), and both irrigation water use efficiencies, were subjected to an one-way analysis of variance using the DSAASTAT add-in version 2011 (Onofri, 2007). A combined analysis of data over both tested years was conducted according to Gomez and Gomez (1984), to recognize dripline spacing whose average effect over years is high and stable. Mean comparison was performed after combined analysis using the least significant difference test (LSD) at the $5 \%$ level of significance.

\subsection{UNCERTAINTIES AND SHORTCOMINGS}

The sugar, protein, oil and starch contents in seeds were not measured, due to the unavailability of the required analysis devices at the time.

As mentioned above, this study used crop coefficient values $(K c)$ of sweet corn as obtained from FAO databases (FAO, 1998), because the values for the tested cultivar were not available. 
Moreover, this study included treatments in which water was applied at full levels for the various dripline spacings. In other words, the irrigation amount was applied on a land-area basis (Eq. 1). The influence of ground cover was not taken into account for drip irrigation scheduling. In other words, a reduction factor was not applied to the ETc calculations. The reason was to avoid the effects of variations in plant growth between treatments, which would have led to variations in the amounts of irrigation water applied.

Due to the absence of accurate data on product prices in the local market due to the huge daily fluctuation of exchange rate, because of the predominant conditions in the country, a partial budget analysis to compare the relative economic rankings of the tested dripline spacings was not conducted. However, a limited data was provided based on the prices of today (May 2020) to economically compare the studied treatments.

\section{RESULTS}

\subsection{IMPACT OF DRIPLINE SPACING ON INTE- GRATED MEASURED TRAITS}

The analysis of variance (ANOVA) indicated no sig- nificant interaction year $\times$ treatment $(p>0.05)$. Therefore, the effects of dripline spacing on the measured parameters were shown as the averages of both tested years, and summarized in Table 2. Moreover, ANOVA revealed that the measured parameters were significantly influenced by the dripline spacing at the $5 \%$ level (Table 2).

Dripline spacing had a strong impact on the plant height, $H$, ( $p<0.05)$. With no significant differences between S75 and S150, both treatments produced the tallest plants up to the beginning of tassels. Then, $\mathrm{H}$ decreased as dripline spacing increased. The smallest mean value of $\mathrm{H}$ was recorded under the $300-\mathrm{cm}$ spacing conditions (Table 2). The maximum value of husked cob length $(18.7 \mathrm{~cm})$ was found under the conventional treatment, S75. Then, it significantly decreased as the dripline spacing increased. The $300 \mathrm{~cm}$ dripline spacing produced cobs significantly shorter by about $20 \%$ than those in S75. No significant differences were recorded between S75 and S150, nor between S225 and S300 (Table 2). Also, dripline spacing treatments differed significantly in term of diameter of husked cobs. The largest cob diameter was produced under both 75 and $150 \mathrm{~cm}$ spacings $(4.8$ and $4.7 \mathrm{~cm}$, respectively); while cobs produced under both 225 and $300 \mathrm{~cm}$ dripline spacings were significantly shorter by about $11 \%$ (Table 2 ). With regard to the mean mass of husked cob (CM), no significant differences were

Table 2: Mean comparisons of crop responses as function of dripline spacings

\begin{tabular}{|c|c|c|c|c|c|c|c|c|}
\hline $\begin{array}{l}\text { Dripline } \\
\text { spacing }\end{array}$ & $\begin{array}{l}\mathrm{H} \\
(\mathrm{cm})\end{array}$ & $\begin{array}{l}\mathrm{CL} \\
(\mathrm{cm})\end{array}$ & $\begin{array}{l}\mathrm{CD} \\
(\mathrm{cm})\end{array}$ & $\begin{array}{l}\text { CM } \\
\left(\mathrm{g} \mathrm{cob}^{-1}\right)\end{array}$ & $\begin{array}{l}\text { DMY } \\
\left(\mathrm{t} \mathrm{ha}^{-1}\right)\end{array}$ & $\begin{array}{l}\text { HCY } \\
\left(\mathrm{t} \mathrm{ha}^{-1}\right)\end{array}$ & $\begin{array}{l}\text { IWUE }_{\mathrm{dm}} \\
\left(\mathrm{kg} \mathrm{m}^{-3}\right)\end{array}$ & $\begin{array}{l}\text { IWUE }_{\mathrm{hc}} \\
\left(\mathrm{kg} \mathrm{m}^{-3}\right)\end{array}$ \\
\hline 2017 season & 161.7 & 18.7 & 4.8 & 211.6 & 7.96 & 13.91 & 1.06 & 1.85 \\
\hline S75 (1:1) & 164.9 & 16.5 & 4.7 & 254.0 & 7.37 & 11.66 & 0.98 & 1.55 \\
\hline S150 (1:2) & 146.8 & 16.2 & 4.3 & 183.7 & 7.46 & 8.75 & 0.99 & 1.16 \\
\hline S225 (1:3) & 136.1 & 15.5 & 4.3 & 223.4 & 6.24 & 6.41 & 0.83 & 0.85 \\
\hline \multicolumn{9}{|l|}{ S300 (1:4) } \\
\hline \multicolumn{9}{|l|}{2018 season } \\
\hline S75 (1:1) & 147.9 & 18.7 & 4.8 & 224.2 & 7.78 & 13.94 & 1.11 & 1.99 \\
\hline S150 (1:2) & 155.5 & 18.5 & 4.8 & 181.2 & 7.98 & 12.95 & 1.14 & 1.85 \\
\hline S225 (1:3) & 133.5 & 15.3 & 4.1 & 181.3 & 8.68 & 9.62 & 1.24 & 1.37 \\
\hline S300 (1:4) & 136.7 & 14.8 & 4.1 & 207.8 & 6.89 & 7.32 & 0.98 & 1.05 \\
\hline \multicolumn{9}{|c|}{ Combined data } \\
\hline S75 (1:1) & $154.8 \mathrm{a}$ & $18.7 \mathrm{a}$ & $4.8 \mathrm{a}$ & $244.3 \mathrm{a}$ & $7.87 \mathrm{a}$ & $13.93 \mathrm{a}$ & $1.08 \mathrm{a}$ & $1.92 \mathrm{a}$ \\
\hline S150 (1:2) & $160.2 \mathrm{a}$ & $17.5 \mathrm{a}$ & $4.7 \mathrm{a}$ & $217.9 \mathrm{a}$ & $7.68 \mathrm{a}$ & $12.30 \mathrm{~b}$ & $1.06 \mathrm{a}$ & $1.70 \mathrm{~b}$ \\
\hline S225 (1:3) & $140.1 \mathrm{~b}$ & $15.8 \mathrm{~b}$ & $4.2 \mathrm{~b}$ & $217.6 \mathrm{a}$ & $8.07 \mathrm{a}$ & $9.18 \quad \mathrm{c}$ & $1.12 \mathrm{a}$ & $1.27 \mathrm{c}$ \\
\hline S300 (1:4) & $136.4 \mathrm{~b}$ & $15.1 \mathrm{~b}$ & $4.2 \mathrm{~b}$ & $182.5 \mathrm{~b}$ & $6.57 \mathrm{~b}$ & 6.86 & $0.91 \mathrm{~b}$ & 0.95 \\
\hline $\mathrm{LSD}_{0.05}$ & 5.57 & 1.41 & 0.18 & 34.25 & 0.94 & 1.39 & 0.13 & 0.19 \\
\hline
\end{tabular}

In each column for combined data, means followed by different letters are significantly different according to LSD test at $5 \%$ level.

$\mathrm{H}=$ plant height, $\mathrm{CL}=$ length of husked cob, $\mathrm{CD}=$ diameter of husked cob, $\mathrm{CM}=$ mass of husked cob, DMY = dry matter yield, $\mathrm{HCY}=$ husked cob yield, IWUEdm = irrigation water use efficiency for dry matter, and IWUEhc = irrigation water use efficiency for husked cobs. 
recorded between S75, S150, and S225 treatments (Table 2). Whereas the $300 \mathrm{~cm}$ dripline spacing produced cobs significantly lighter $\left(182.5 \mathrm{~g} \mathrm{cob}^{-1}\right)$.

The integrated dry matter yield (DMY) varied significantly among treatments, ranging from the lowest value of $6.57 \mathrm{t} \mathrm{ha}^{-1}$ in $\mathrm{S} 300$ treatment to the highest of $8.07 \mathrm{t} \mathrm{ha}^{-1}$ in S225 treatment. No significant differences were detected between S75, S150, and S225 at the $5 \%$ level (Table 2). Furthermore, mean integrated yields varied widely among treatments (Table 2 ). The highest value (13.93 $\mathrm{t} \mathrm{ha}^{-1}$ ) was found under the $75 \mathrm{~cm}$ spacing. After that, it significantly decreased as the dripline spacing increased. The mean integrated yields in S150, S225, and S300 were reduced by $11.7,34.0$, and $50.7 \%$, respectively, compared with that of the $75 \mathrm{~cm}$ spacing (Table 2).

As mentioned earlier, all dripline spacing treatments received at each irrigation event the same amount of water per unit area (the same irrigation water depth), and treatments differed in terms of irrigation times according to the dripline spacing. Each dripline spacing treatment received about $653 \mathrm{~mm}$ in 2017, and $600 \mathrm{~mm}$ in 2018, of drip irrigation water amounts. The times of drip irrigation events applied to S75, S150, S225, and S300 were 49, 98, 147, and $196 \mathrm{hr}$ in 2017, and 45, 90, 135, and 180 hr in 2018, respectively. Consequently, the total amounts of irrigation water were for each treatment $753 \mathrm{~mm}$ in 2017, and $700 \mathrm{~mm}$ in 2018, respectively. Although the climate data for both studied years were close to the 20year mean, the difference in irrigation water amounts applied in the two years could be due to the timing of high evapotranspiration days and to the earliness in planting day in the 2018-cropping season.

For IWUE $_{\mathrm{dm}}$, no significant differences were recorded between S75, S150, and S225. The maximum value was observed under S225 $\left(1.12 \mathrm{~kg} \mathrm{~m}^{-3}\right)$. The wider dripline spacing treatment (S300) significantly decreased IWUE $_{\mathrm{dm}}$ by about $17 \%$ relative to the other treatments (Table 2). Irrigation water use efficiency for economic
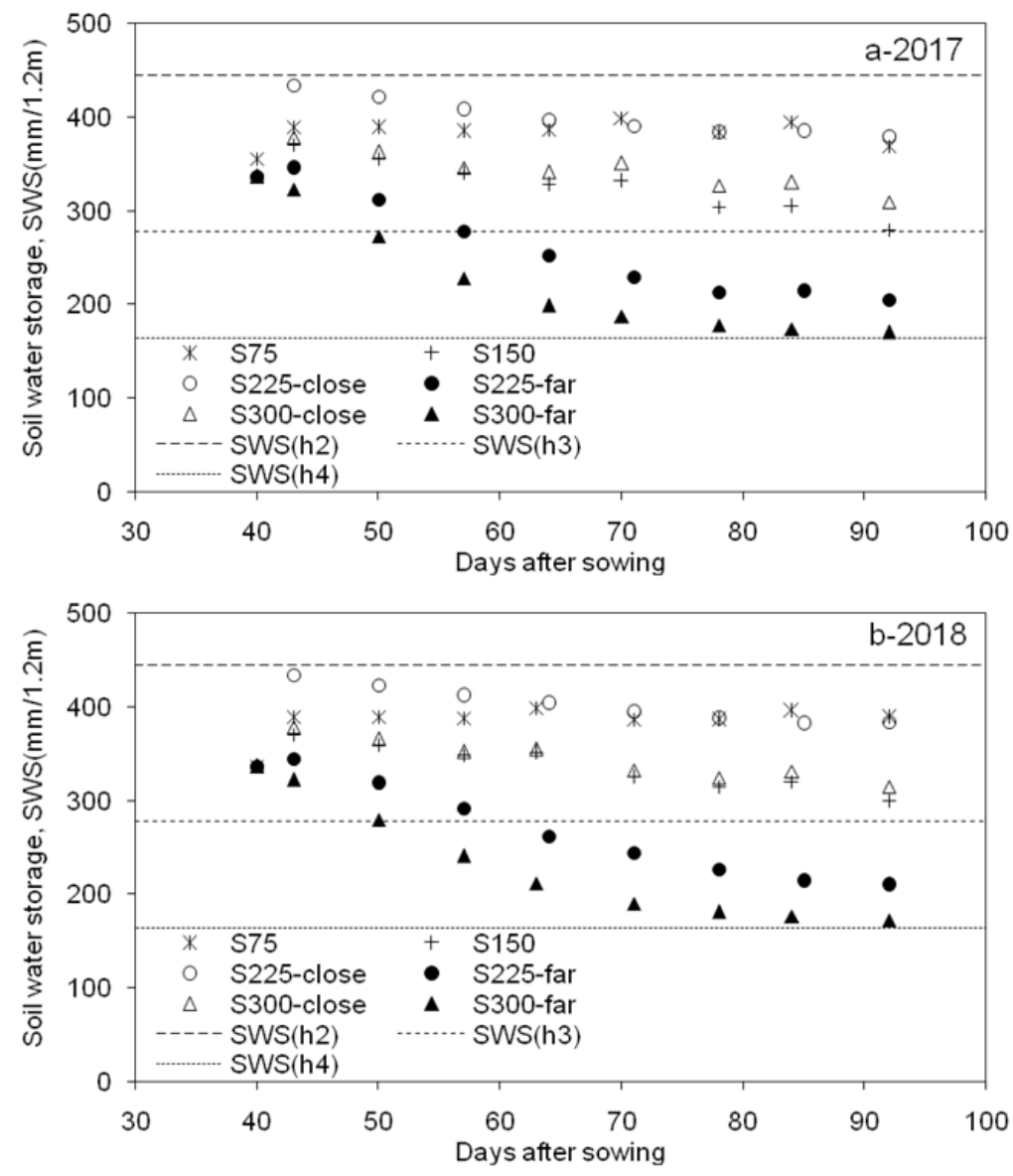

Figure 2: Changes over time in soil water storages in $120 \mathrm{~cm}$ soil profile for 2017 (a) and 2018 (b) growing seasons. Dashed lines represent soil water storages at $h 2, h 3$, and $h 4$ corresponding to the root water uptake parameters for sweet corn crop as suggested by Feddes et al. (1978). S75, S150, S225, and S300 represent dripline spacings treatments. "close" and "far" represent the row next to the dripline and the distant row from the dripline, respectively. 
yield (husked cob yield), IWUE ${ }_{\text {hc }}$, significantly decreased as dripline spacing increased. The highest value was observed under S75 $\left(1.92 \mathrm{~kg} \mathrm{~m}^{-3}\right)$. IWUE ${ }_{\mathrm{hc}}$ under S150, S225, S300 were, respectively, 11.7, 34.0, and $50.7 \%$ less than that under S75, which followed the reduction percentage trend of HCY (Table 2).

\subsection{IMPACT OF DRIPLINE SPACING ON SOIL WATER STATUS}

Variations over time in weekly measured soil water storages (SWS) are shown in Figure 2 for both growing seasons. Soil water storages at the rows close to driplines varied from one treatment to another, but still remained between SWS $\left(h_{2}\right)$ and SWS $\left(h_{3}\right)$, where root water uptake is maximal according to Feddes et al. (1978). This indicated that no water stress throughout the whole growing season was exposed on the corn plants (Figs. 2 a and b). This can be attributed to the fact that the crop rows closest to driplines have more favorable soil water conditions. However, in both growing seasons, irrigation maintained the soil water storage at a fairly constant and high level under the conventional $75 \mathrm{~cm}$ dripline spacing relative to the other treatments. This indicated that the $75 \mathrm{~cm} \mathrm{spac}-$ ing was adequately providing crop water requirements.

When using wider dripline spacings, as for both S225 and S300 treatments, soil water storages remarkably decreased at the distant crop rows from driplines. Their values soon dropped below the lower limit of optimal range of root water uptake, SWS $\left(h_{3}\right)$, below which roots can no longer extract water at the maximum rate, and the transpiration was reduced below potential rate (Feddes et al., 1978). Thus, the distant rows for both treatments S225 and S300 were susceptible to water stress starting from the end of development stages (about 50 and 60 days after sowing day for S300 and S225, respectively). The degree of water stress excessively increased during the reproductive stages towards the late stage. However, their values did not drop below the lowest limit SWS $\left(h_{4}\right)$, below which root water uptake was zero reaching the wilting point pressure head.

\subsection{IMPACT OF DRIPLINE SPACING ON INDI- VIDUAL CROP ROW YIELDS}

The effects of dripline spacing on individual crop row yields are illustrated in Figure 3 for husked cob yield and in Figure 4 for dry matter yield. In order to show the yield distributions of the different treatments, a mirror image of yields versus a dripline was used. Large yield differences between rows took place as distance from the dripline to the crop row increased. Both HCY and DMY increased as the crop rows were moved closer to the driplines. In the $300-\mathrm{cm}$ dripline spacing, the husked cob yield (HCY) for the interior rows (rows close to the dripline) was $94.5 \%$ higher than for the exterior rows (rows far away from the dripline). Moreover, the dry matter yield (DMY) for the interior rows was $44.5 \%$ higher than for the exterior rows. However, they were $60.6 \%$ for HCY and only $18.7 \%$ for DMY under the $225-\mathrm{cm}$ spacing conditions (Figs. 3 and 4).

On the other hand, for the same distance of crop row from dripline, expected results occurred under both wider dripline spacings (S225 and S300) conditions com-

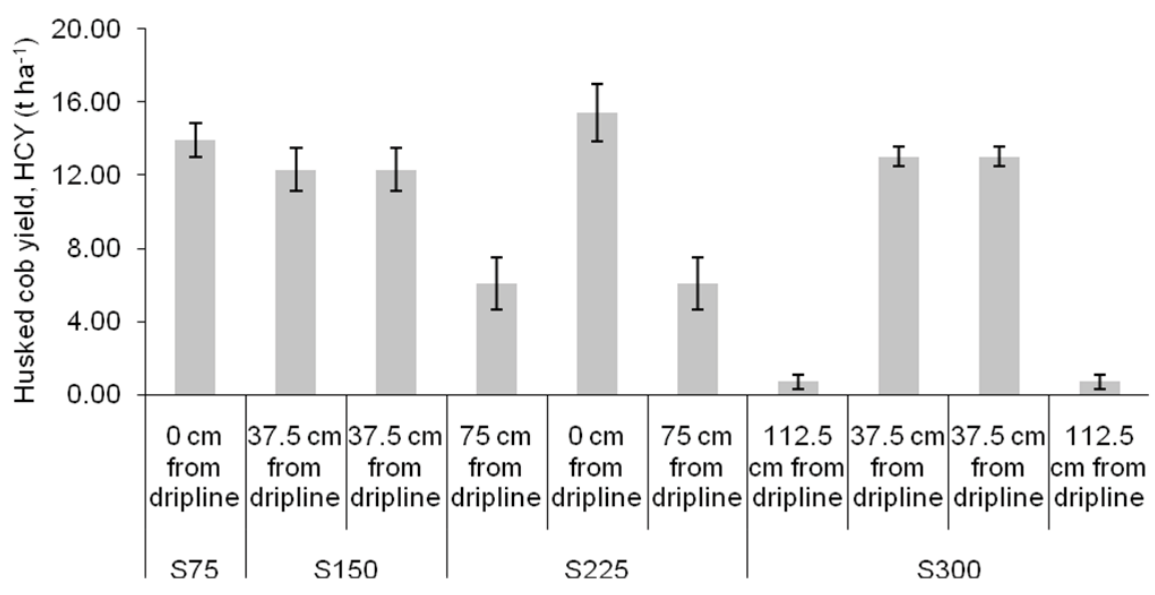

Figure 3: Husked cob yield distribution according to the distance from dripline for the combined data of both tested seasons. Individual crop row yields are mirrored about the dripline in each treatment for display purposes. S75, S150, S225, and S300 represent dripline spacing treatments. Error bars represent the standard deviations. 


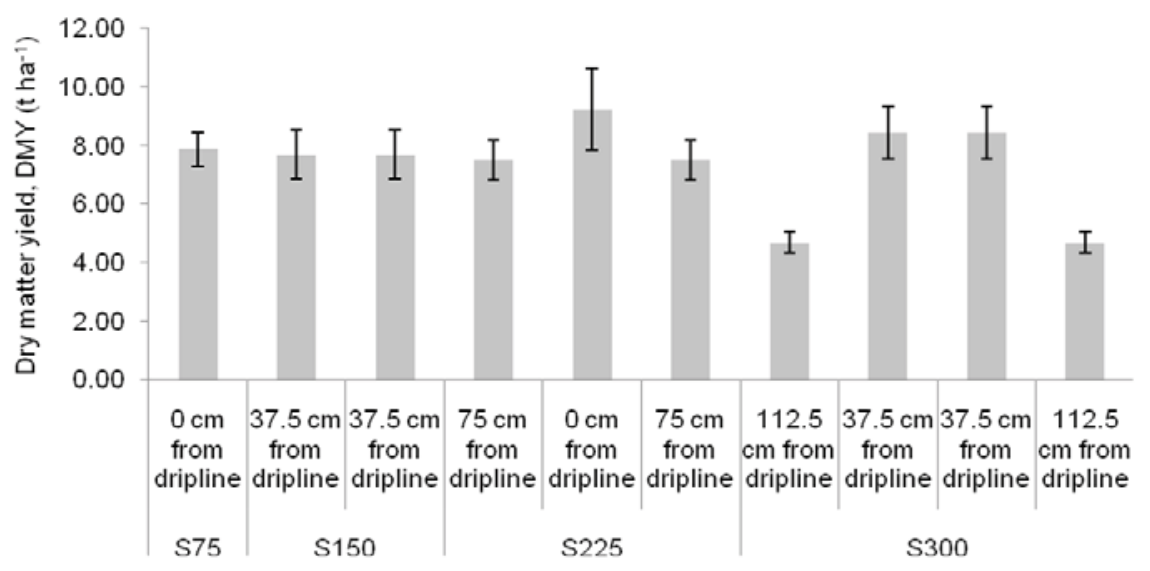

Figure 4: Dry matter yield distribution according to the distance from dripline for the combined data of both tested seasons. Individual crop row yields are mirrored about the dripline in each treatment for display purposes. S75, S150, S225, and S300 represent dripline spacing treatments. Error bars represent the standard deviations.

pared with S75 and S150 conditions. For the crop rows placed at $37.5 \mathrm{~cm}$ from dripline as in both S150 and S300 treatments, the husked cob yields were somewhat similar (12.30 and $13.02 \mathrm{t} \mathrm{ha}^{-1}$ in S150 and S300, respectively). While for the crop rows placed at $0 \mathrm{~cm}$ from dripline as in both S75 and S225 treatments, the husked cob yield in S225 (the interior rows) (15.41 $\left.\mathrm{t} \mathrm{ha}^{-1}\right)$ was $10 \%$ higher than their analogues under S75 (13.93 $\left.\mathrm{t} \mathrm{ha}^{-1}\right)$ (Fig. 3). In addition, the dry matter yields for the interior rows in both S225 and S300 were almost higher than those under both S75 and S150, respectively (Fig. 4).

\section{DISCUSSION}

As different dripline spacings were tested, one dripline served one or several plant rows, and therefore, rootzone soil water content was spatially variable and depended on the distance from the dripline. Results indicated insufficient supply of irrigation water to the points of rootzone very distant from dripline, and consequently, water distribution was inappropriate for the wider dripline spacings, even with the same amount of irrigation water applied. This result is in agreement with other published findings by Lamm et al. (1997) who found that soil water storages were reduced an additional 20 to $40 \%$ by the crop rows placed away from the driplines at $114 \mathrm{~cm}$, relative to those at crop rows growing next to driplines at $38 \mathrm{~cm}$. They demonstrated that water supply was improper for the wider dripline spacings, even with full irrigation. Bozkurt et al. (2006) assessed also the effects of different dripline spacings $(70,140$, and $210 \mathrm{~cm})$ on yield and yield components of corn crop, and reported that insufficient irrigation water was supplied to crops away from the dripline, even under full irrigation. This water stress was gradually increased under deficit irrigation conditions especially in the wider spacing treatments.

The row-to-row yield variation was enormous under the 300-cm spacing conditions, and less sharply under $225 \mathrm{~cm}$ spacing treatment. This row-to-row variation was attributed to the spatial variation in rootzone soil water status. In plots with the 225 and $300 \mathrm{~cm}$ dripline spacings, the crop rows in the immediate vicinity of the dripline received a higher water amount than those away from the dripline. As mentioned above, the furthest crop rows were more water stressed than rows adjacent to the dripline. Thus, yields of the interior crop rows (next to the driplines) in 225 and $300 \mathrm{~cm}$ spacings were found higher or equal to those of 75 and $150 \mathrm{~cm}$ spacings. This could be due to the extra water available for the interior rows in the wider dripline spacings, mitigating the severity of wetting-drying cycle between two irrigation events. Moreover, this more favourable soil water condition may stimulate plants to consume more nutrients. Another possibility is that the furthest crop rows from dripline were short in height due to the soil water stress (data not shown). This could allow more sunlight into the crop canopy of the interior rows, resulting in higher yields (Dalley et al., 2004; Bradley, 2006). This is in agreement with several experimental results which found that non-uniformity of yield with the distance from the dripline negatively affects the total yield. Lamm et al. (1997) reported significant effect of row spacing across dripline on corn yield under subsurface drip irrigation system, and documented that the row-to-row variation could reach more than 67 and $41 \%$ for 230 and $300 \mathrm{~cm}$ dripline spacings, respectively. These yield reductions could attain $95 \%$ in both dripline spacings under deficit irriga- 
tion conditions. However, Bozkurt et al. (2006) reported that yield from the wider dripline spacing $(210 \mathrm{~cm})$ with full irrigation for the closest and furthest crop rows from the dripline was only 8.2 and $9.6 \%$ lower, respectively, than that of the optimum dripline spacing $(140 \mathrm{~cm})$. These reductions in yields reached 25.9 and $36.9 \%$, respectively, when irrigation level reduced to $67 \%$ of crop water needs.

Results indicated that rootzone soil water status enhanced as the plant rows were moved closer to the driplines. This was reflected in the integrated traits, i.e., plant height, ear characteristics, yields, and irrigation water use efficiency. They were found to be decreased as the dripline spacing increased. Similar results for husked cob length, diameter, and mass were reported by previous studies (e.g. Al-hurmuzi and Topak, 2018; Mubarak, 2020a and b). However, Bozkurt et al. (2006) reported that the effects of different dripline spacings on cob length were statistically insignificant, but cob length was reasonably higher in full irrigation relative to the deficit irrigation condition. Similar yields to those obtained herein were also found by Ertek and Kara (2013) when a dripline per crop row was used. They reported that the fresh cob yield of sweet corn reached $14.74 \mathrm{t} \mathrm{ha}^{-1}$. A fresh cob yield of sweet corn of $13.43 \mathrm{t} \mathrm{ha}^{-1}$ was also reported by Oktem et al. (2003). Basava (2012) studied the effects of one dripline for two sweet corn crop rows at $120 \mathrm{~cm}$, and reported a fresh cob yield of $12.83 \mathrm{t} \mathrm{ha}^{-1}$ under full irrigation level. Lamm et al. (1997) showed that mean corn yields were 13.6, 12.8, and $12.2 \mathrm{t} \mathrm{ha}^{-1}$ for 150,230 , and $300 \mathrm{~cm}$ dripline spacings, respectively, for a total irrigation volume of $462 \mathrm{~mm}$, using subsurface drip irrigation. Corn yields reduced to 10.8 and $9.3 \mathrm{t} \mathrm{ha}^{-1}$ when irrigation level was decreased by 33 and $50 \%$ for the wider dripline spacings of 230 and $300 \mathrm{~cm}$, respectively. However, Sorensen and Lamb (2008) found that corn yield showed no difference between 91 and $183 \mathrm{~cm}$ dripline spacings. Moreover, Bozkurt et al. (2006) reported that the mean corn yields were $8.57,9.79$, and $8.92 \mathrm{tha}^{-1}$ for 70,140 , and $210 \mathrm{~cm}$ dripline spacings, respectively for a full irrigation with a total amount of about $750 \mathrm{~mm}$, using surface drip irrigation. Different from our findings, those authors documented that the wider dripline spacing $(140 \mathrm{~cm})$ was better than the closer dripline spacing $(70 \mathrm{~cm})$ under full irrigation.

A partial budget analysis should have been conducted to compare the relative economic rankings of the tested dripline spacings. A limited data could be provided based on the prices of today (May 2020). The local price of sweet corn is about 150 USD per tonne. The cost of dripline plus the cost of its laying out on the field is about 0.30 USD per meter. As mentioned above, HCYs were 13.93, 12.30, 9.18 and $6.86 \mathrm{t} \mathrm{ha}^{-1}$ in S75, S150, S225 and
S300, respectively (Table 2). The total incomes from the harvested husked cobs were about 2090, 1845, 1377 and 1029 USD per year, respectively. As well, the initial costs of driplines were about 4000, 2000, 1333 and 1000 USD per hectare, respectively. Hence, the production of two growing seasons under $\mathrm{S} 75$ conditions (the $75 \mathrm{~cm}$ spacing) would be needed in order to recover the initial costs of driplines, assuming the consistency of yield over years. However, the production of only one season would be needed to recover the initial costs in the wider spacings.

The S150, S225 and S300 produced, respectively, about 1.63, 4.75 and $7.07 \mathrm{t} \mathrm{ha}^{-1}$ less than S75. This means a loss of 245, 713 and 1061 USD per hectare, respectively, as compared with S75. However, the wider dripline spacing, the higher initial unit-area dripline cost savings, attaining 50, 66.7, and $75 \%$ for the 150,225 , and $300 \mathrm{~cm}$ spacings, respectively, relative to that in the conventional $75 \mathrm{~cm}$ dripline spacing. In other words, the initial unitarea dripline cost savings are 2000, 2667 and 3000 USD per hectare, respectively. Hence, the reduction in crop yield due to the wider dripline spacings did not justify the extra cost of the closer dripline spacing. This result agreed well with the findings of other studies (Lamm et al., 1997; Bozkurt et al. 2006).

Moreover, reducing the quantity of driplines in unit area according to the dripline spacings reveals decreases in terms of main pipeline diameter, related accessories and pumping requirements, from the point of view of irrigation network design. Moreover, it reduces the harmful environmental impacts resulting from broken plastic components. Although the irrigation times was 2, 3, and 4 times as much of S75 treatment, when using 150, 225, and $300 \mathrm{~cm}$ dripline spacings, respectively, the decreases in the pump unit capacity probably compensate the total electric energy needed over the growing season in comparison to the other treatments, also from a design perspective.

Otherwise, results of a simulation study using Hydrus2D code performed on the herein tested treatments (data not shown) demonstrated that an important portion of water amounts provided by irrigation were lost by deep percolation, when using the wider lateral spacing. The highest deep-percolated volume was occurred under S300 conditions, with more than $10 \%$ of the total amount of irrigation water were deep-percolated under the $150 \mathrm{~cm}$ soil depth. The deep percolation of irrigation water which carries much of the mobile nutrients can adversely affect the environment and the groundwater quality. This reveals that the $300 \mathrm{~cm}$ dripline spacing is not suitable for the environmental protection due to deep percolation losses under the study context.

The maximum two-year average husked cob yield was observed under $75 \mathrm{~cm}$ dripline spacing, and then it 
significantly decreased as dripline spacing increased as above mentioned. Some farmers may find the wider dripline spacings not suitable for the drip-irrigated sweet corn production due to long irrigation set times, nonuniformity of the corn field scene, and probable deep percolation losses. Nevertheless, although the yield reductions under wider dripline spacings involved economically considerable losses at the high overall levels, they did not justify the extra cost of the closer dripline spacing, at very low crop prices and very high dripline costs.

\section{CONCLUSION}

Increasing the spacing between driplines has been recognized as the most significant factor in reducing the high initial costs of drip irrigation system. Nevertheless, almost none research findings are presently available on sweet corn response to the same tested planting arrangement (i.e., using one dripline for three or four crop rows of sweet corn) grown in the dry Mediterranean area. The $75 \mathrm{~cm}$ dripline spacing conditions produced the maximum two-year average husked cob yield (13.93 t ha-1), and the irrigation water use efficiency $\left(1.92 \mathrm{~kg} \mathrm{~m}^{-3}\right)$. Although the 150, 225 and $300 \mathrm{~cm}$ spacings yielded, respectively, $11.7,34.0$ and $50.8 \%$ less than the $75 \mathrm{~cm}$ dripline spacing, these wider dripline spacings provided 50, 67 and $75 \%$ less unit-area dripline cost, respectively. These reductions in crop yield did not justify the extra cost of the closer dripline spacing. The production of two seasons would be needed to recover the initial dripline costs under closer dripline spacing. However, the production of only one season would be needed for the wider spacings. Hence, using wider dripline spacings would be economically justified at low crop prices and high dripline costs.

The sugar, protein, oil and starch contents in seeds were not measured, while economic yields and irrigation water use efficiency and some plant and cob characteristics were presented. This study used crop coefficient values $(K c)$ of sweet corn as obtained from FAO databases. Moreover, this study included treatments in which water was applied at full levels, so that the irrigation amount was applied on a land-area basis. The influence of ground cover was not taken into account for drip irrigation scheduling in order to avoid the effects of variations in plant growth between treatments, which would have led to variations in the amounts of irrigation water applied. A limited data was provided based on the prices of today to economically compare the studied treatments, due to the absence of accurate data on product prices in the lo- cal market because of the predominant conditions in the country.

The outcomes of this study were conveyed to the policymakers (the Ministry of Agriculture and Agrarian Reform) in order to adopt the practical alternatives based on the obtained results and to make the wider dripline spacings in sweet corn crop production system familiar for most farmers. It is requested to stimulate farmers to adopt the proposed alternatives in their fields to sustain corn productivity, to reduce the high initial costs of drip irrigation system.

For the scientific community, our findings demonstrated that wide dripline spacings resulted in less driplines in unit area, less related accessories and fewer requirements of pump unit capacity. This may contribute to introduce practical alternative to meet sustainable crop production, water shortage, and environmental protection in the dry Mediterranean region.

Finally, further studies are needed in order to benefit from the higher initial unit-area dripline cost savings obtained under wider spacings. Adopting suitable techniques, such as using multiple-row production systems, may enhance soil water status and root water uptake, and therefore, final fresh yield. Moreover, further studies should include treatments in which water was applied at reduced levels (not only at full levels as in this study) for the various spacings, in order to determine if the irrigation amount should be applied on a land-area basis (full) or in relation to number of driplines in plots (reduced). The fraction of the total surface area actually covered by the foliage of the plants (ground cover) should be also applied for irrigation scheduling under drip irrigation. Moreover, it is recommended to study the influences of tested planting arrangement on sugar, protein, oil and starch contents in seeds.

\section{ACKNOWLEDGEMENT}

The authors would like to thank the Atomic Energy Commission of Syria for encouragement and support.

\section{REFERENCES}

Al-hurmuzi, J. O. H., Topak, R. (2018). Lateral spacing affect on yield and quality attributes of drip-irrigated sweet corn. Selcuk Journal of Agricultural and Food Sciences, 32(1), 5559. https://doi.org/10.15316/SJAFS.2018.64

Basava, S. (2012). Performance of sweet corn hybrid under different levels of irrigation and nitrogen applied through drip system. Master of Science in Agriculture, Acharya N. G. Ranga Agricultural University, Hyderabad.

Bordovsky, J. P., Porter, D. (2003). Cotton response to preplant 
irrigation level and irrigation capacity using spray, LEPA, and subsurface drip irrigation. ASAE Paper No. 032008. St. Joseph, Mich.: American Society of Agricultural Engineers.

Bosch D.J., Powell N.L., Wright F.S. (1998). Investment returns from three subsurface microirrigation tubing spacings. Journal of Production Agriculture, 11(3), 371-376. https:// doi.org/10.2134/jpa1998.0371

Bozkurt, Y., Yazar, A., Gencel, B., Sezen, M. S. (2006). Optimum lateral spacing for drip-irrigated corn in the Mediterranean Region of Turkey. Agricultural Water Management, 85, 113 120. https://doi.org/10.1016/j.agwat.2006.03.019

Bradley, K. W. (2006). A review of the effects of row spacing on weed management in corn and soybean. Crop Management. https://doi.org/10.1094/CM-2006-0227-02-RV

Camp, C. R., Sadler, E. J., Busscher, W. J. (1989). Subsurface and alternate-middle microirrigation for the southeastern Coastal Plain. Transactions of the American Society of Agricultural Engineers, 32(2), 451-456. https://doi. org/10.13031/2013.31025

Camp, C. R., Bauer, P. J., Hunt, P. G. (1997). Subsurface drip irrigation lateral spacing and management for cotton in the southeastern Coastal Plain. Transactions of the American Society of Agricultural Engineers, 40(4), 993-999. https:// doi.org/10.13031/2013.21351

Camp, C. R. (1998). Subsurface drip irrigation: a review. Transactions of the American Society of Agricultural Engineers, 41(5), 1353-1367. https://doi.org/10.13031/2013.17309

Charlesworth, P. B., Christen, E. W., de Vries, T. (1998). Is S.I.P. (Draincoil) a cheap alternative to drip irrigation? In Water is Gold: National Conference and Exhibition Proceeding, 499-506.

Charlesworth, P. B., Muirhead, W. A. (2003). Crop establishment using subsurface drip irrigation: A comparison of point and area sources. Irrigation Science, 22(3-4), 171-176. https://doi.org/10.1007/s00271-003-0082-6

Clemmens, A. J., (2002). Measuring and improving irrigation performance at the field level. Transactions of the American Society of Agricultural Engineers, 22(8), 89-96.

Dalley, C. B., Kells, J. J., Renner, K. A. (2004). Effect of glyphosate application timing and row spacing on weed growth in corn (Zea mays) and soybean (Glycine max). Weed Technology, 18, 177-182. https://doi.org/10.1614/02-150B

Ertek, A., Kara, B. (2013). Yield and quality of sweet corn under deficit irrigation. Agricultural Water Management, 129, 138-144. https://doi.org/10.1016/j.agwat.2013.07.012

FAO. (1998). Crop evapotranspiration: guidelines for computing crop requirements (FAO Irrigation and Drainage Paper No. 56).

Feddes, R. A., Kowalik, P. J., Zaradny, H. (1978). Simulation of Field Water Use and Crop Yield. Wiley, New York.

Gomez, K. A., Gomez, A. A. (1984). Statistical Procedures for Agricultural Research ( $2^{\text {nd }}$ ed.). New York, NY: John Wiley \& Sons.

Henggeler, J. C. (1995). A history of drip-irrigated cotton in Texas. In Microirrigation for a Changing World: Conserving Resources/Preserving the Environment, Proceeding. $5^{\text {th }}$ International Microirrigation Congress, 669-674. F. R. Lamm, ed. St. Joseph, Mich.: American Society of Agricultural Engineers.
Howell, T. A., Schneider, A. D., Evett, S. D. (1997). Subsurface and surface microirrigation of corn-Southern High Plains. Transactions of the American Society of Agricultural Engineers, 40(3), 635-641. https://doi.org/10.13031/2013.21322

Kruse, E. G., Israeli, I. (1987). Evaluation of a subsurface drip irrigation system. Presented at the 1987 Summer Meeting of the American Society of Agricultural Engineers. ASAE Paper No. 87-2034. American Society of Agricultural Engineers, St. Joseph, Michigan, 21 pp.

Lamm, F. R., Stone, L. R. Manges, H. L., O’Brien, D. M. (1997). Optimum lateral spacing for subsurface dripirrigated corn. Transactions of the American Society of Agricultural Engineers, 40(4), 1021-1027. https://doi. org/10.13031/2013.21354

Lamm, F. R., Trooien, T. P., (2003). Subsurface drip irrigation for corn production: A review of 10 years of research in Kansas. Irrigation Science, 22(3-4), 195-200. https://doi. org/10.1007/s00271-003-0085-3

Mubarak, I., (2020)a. Triple-row system with a wider drip-line lateral spacing for two drip-irrigated sweet corn cultivars. Pesquisa Agropecuaria Brasileira, 55, e01684. https://doi. org/10.1590/S1678-3921.pab2020.v55.01684. 2020.

Mubarak, I., (2020)b. The response of two drip-irrigated sweet corn varieties to the twin-row production system in the dry Mediterranean region. The Open Agriculture Journal, 14, 9-15. https://doi.org/10.2174/1874331502014010009

Oktem, A., Simsek, M., Oktem, A. G. (2003). Deficit irrigation effects on sweet corn with drip irrigation system in semi arid region: I. water-yield relationship. Agricultural Water Management, 61, 63-74. https://doi.org/10.1016/S03783774(02)00161-0

Onofri, A. (2007). Routine statistical analyses of field experiments by using an Excel extension. National Conference Italian Biometric Society. Proceeding $6^{\text {th }}$ (Pisa). In: "La statistica nelle scienze della vita e dell'ambiente"; 20-22, 93-96.

Powell, N. L., Wright, F. S. (1993). Grain yield of subsurface microirrigated corn as affected by irrigation line spacing. Agronomy Journal, 85(6), 1164-1169. https://doi. org/10.2134/agronj1993.00021962008500060014x

Sorensen, R. B., Lamb, M. C. (2008). Corn and cotton yield with two surface drip lateral spacings. Crop Management, https://doi.org/10.1094/CM-2008-0118-01-RS

Spurgeon, W. E., Manges, H. L. (1990). Drip line spacing and plant population for corn. In: Proceeding of the Third National Irrigation Symposium, Phoenix, Arizona, October 28-November 1, 1990, pp. 217-222.

Thorburn, P. J., Cook, F. J., Bristow, K. L. (2003). Soil-dependent wetting from trickle emitters: implications for trickle design and management. Irrigation Science, 22, 121-127. https://doi.org/10.1007/s00271-003-0077-3

Tiercelin, J. R., (2007). Traité d'irrigation. Lavoisier Tec\&Doc Edition.

Zhou, L. F., Feng, H., Zhao, Y., Qi, Z. J., Zhang, T. B., He, J. Q., Dyck, M. (2017). Drip irrigation lateral spacing and mulching affects the wetting pattern, shoot-root regulation, and yield of maize in a sand-layered soil. Agricultural Water Management, 184, 114-123. https://doi.org/10.1016/j.agwat.2017.01.008 